\title{
気象変化に伴う中海 - 大橋川 - 宍道湖の水位変動 WATER LEVEL CHANGE IN THE LAKE NAKAUMI, OHASHI RIVER AND LAKE SHINJI DUE TO METEOROLOGICAL CONDITION CHANGE
}

\author{
福岡捷二 $1 \cdot$ 岡村誠司 $2 \cdot$ 松下智美 $3 \cdot$ 船橋昇治 4 \\ Shoji FUKUOKA, Seiji OKAMURA, Tomomi MATSUSHITA and Shoji FUNABASHI \\ 1フェロー会員 Ph.D 工博 広島大学大学院教授 社会環境システム専攻（テ739-8527 広島県東広島市鏡山 1-4-1） \\ 2 学生会員 広島大学大学院 工学研究科社会環境システム専攻博士課程前期（同上） \\ 3 学牛会員 広島大学大学院 工学研究科社会環境システム専攻博士課程前期（同上） \\ 4 正会員 工修 国土交通省中国地方整備局出雲工事事務所所長（广T693-0023 島根県出雲市塩冶有原町 5-1）
}

\begin{abstract}
To solve the water quality problems in the Lake Nakaumi and the Lake Shinji, it is necessary to make clear the characteristics of flow and water level variation in these two lakes. Flows in these two lakes are dependent on each other, because these two lakes are connected by the Ohashi River. We have to investigate flows in the Lake Nakaumi, the Lake Shinji and the Ohashi River together.

We compared meteorological external forces, the water level variation and the flow of the Lake Shinji with those of the Lake Nakaumi. We made clear the propagation mechanism of water level variation in the Lake Nakaumi, the Lake Shinji and the Ohashi River, respectively, by calculating time lags of water level variations in many observation points. Furthermore, the propagation mechanism of water level changes by wind set up was also investigated.
\end{abstract}

\section{Key Words : brackish lake, Lake Nakaumi, Lake Shinji, Ohashi River, water level, wind-driven current, propagation of water level change}

\section{1. 序論}

図-1に示すように, 中海と梥道湖は斐伊川と日本海の 境に位置し大橋川により連結されている，そのため河川 から淡水が流入する一方で, 美保湾からは海水が流れ込 み, 国内でも有数の汽水域を形成している. 中海と宾道 湖には, 天体力や気圧変化に起因する外海水位変動, 風, 河川水の流入などの外力が作用し, 複雑な水位変動や湖 内流動, 水交換が生じる. それに伴い, 水域の物理環境・ 水質環境が変化する 1，2），中海・实道湖内および大橋川 内の流動に関する従来の研究は，単独の湖また注河川を 対象になされてきた ${ }^{3} ， 4$ )，5)。しかし，中海と宾道湖の水 位変動や流動は大橋川を介して互いに影響を及ぼし合っ ているため, 連結系汽水湖である中海 - 大橋川 - 宍道湖 を一体的に検討する必要がある. その基礎的段階として, 本研究では最初に, 中海. 实道湖に作用する気象外力と, 気象外力により 2 つ湖で生じる水位変動・流動特性を

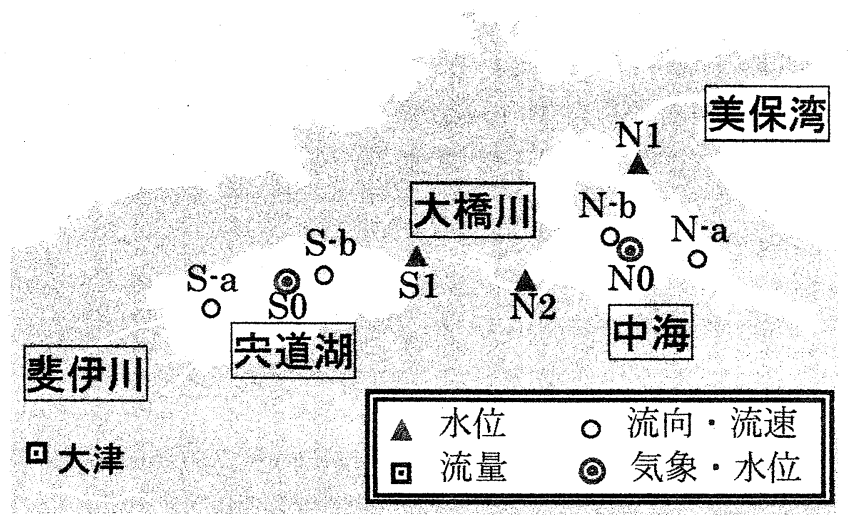

図-1＼cjkstart観測地点と観測項目

比較検討する．次に，気圧変化に伴う周期の明確でない 外海水位変動が, 中海内や穴道湖内を伝播する機構, お よび大橋川を介して中海から宍道湖へ伝播する機構を明 らかにする. 最後に, 風の吹き寄せ効果により中海内, 宾道湖内に生じる水位の変化を評価する. 

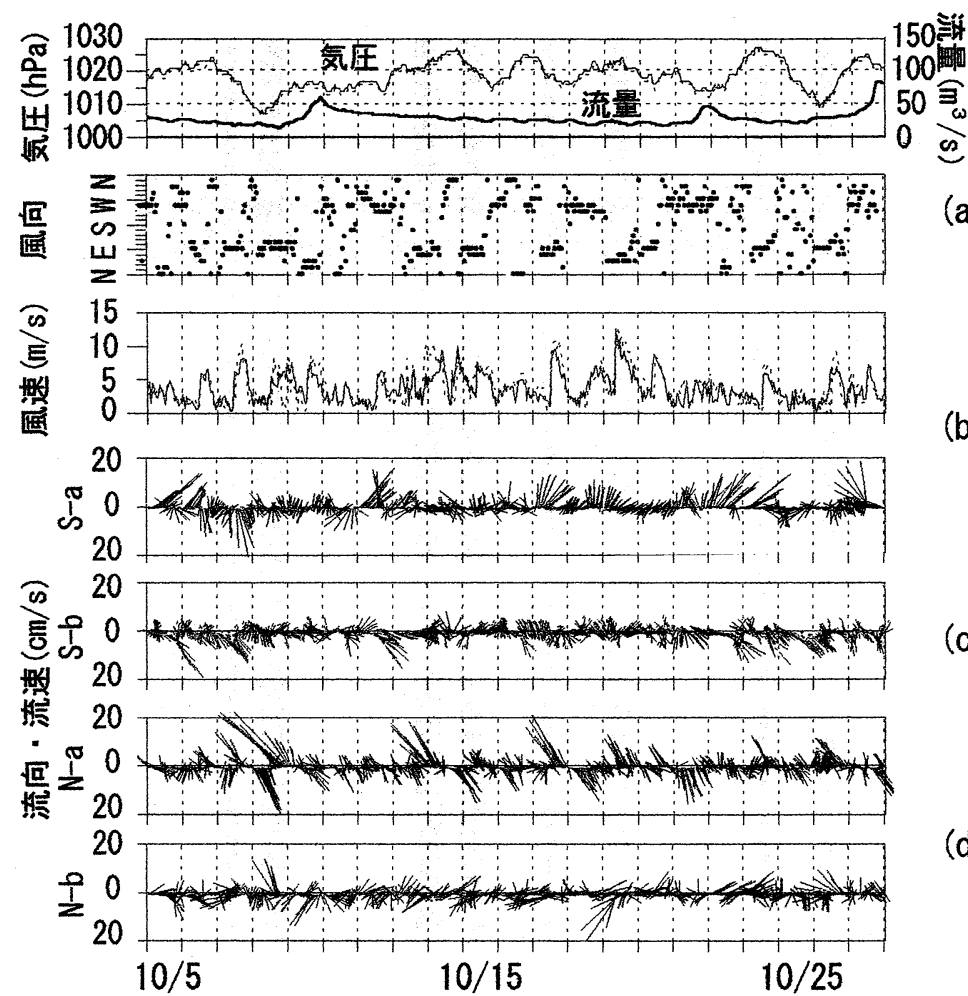

図-2 観測地点 N0.SO における気圧，風向·風速と中海·宾 道湖内流向・流速と大津流量（2000 年 10/5 10/25）

\section{2. 観測方法}

2000 年 10 月に行った 1 ケ月間連続観測において, 図 -1 に示守観測地点 $\mathrm{N} \cdot \mathrm{a}, \mathrm{N} \cdot \mathrm{b}, \mathrm{S} \cdot \mathrm{a}, \mathrm{S} \cdot \mathrm{b}$ の水面下 $1.0 \mathrm{~m}$ で測定された流向・流速と，同期間に No，S0 で測定さ れた気圧, 風向・風速より, 気象外力, および気象外力に より生じる流動の検討を行う.

また, 観測地点 N0 (中海湖心), N1 (中海の入り口), $\mathrm{N} 2$ (大橋川の下流端)，S0 (宾道湖湖心)， S1 (大橋川 の上流端）において 1998 年 1 月〜 12 月の一年間 1 時間 毎に測定された水位と, 同期間中に観測地点 No, S0 で 測定された風向·風速, 大津で測定された斐伊川流量を用 いて水位変動の検討を行う。

\section{3. 気象外力と中海・宍道湖の流動特性}

図-2に, 2000 年 10/5 10/25 の期間中に観測地点 N0, S0 において測定された気圧，風向·風速，大津において 測定された斐伊川流量, および観測地点 S-a, S-b, N-a, $\mathrm{N}-\mathrm{b}$ の水面下 $1.0 \mathrm{~m}$ における流向・流速を示す.

気圧に着目すると, 観測地点 No と S0 における気圧 変動は一致している.このことから二つの湖上での気圧 差が引き起こすような中海, 宍道湖閒の水交換や水位変 動はないことがわかる。

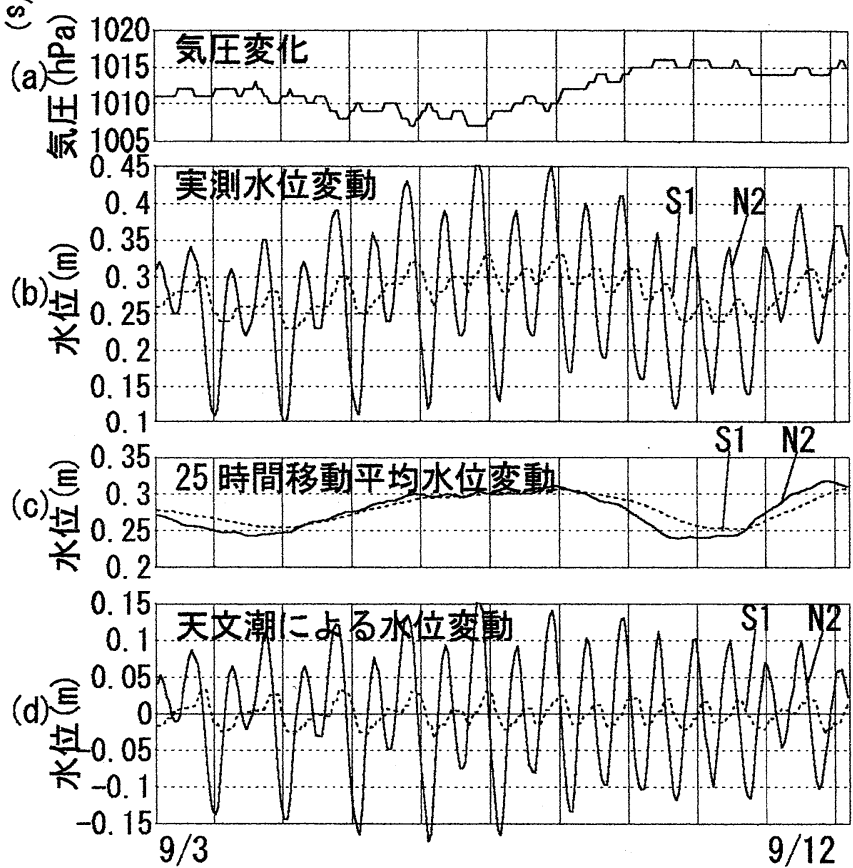

図-3 観測地点 N0 における気圧と N2, S1 水位の成分分解 (1998 年 9/3 9/12)

風向・風速に着目すると, 観測地点 No, S0 ともに風 向は北東〜東 (北東〜東方向から吹く風のこと), 南西〜 西が卓越しており, 特に風向が北東〜東のときに風速が 大きくなる傾向がある. これは, 中海, 宍道湖が南北を 山地に挟まれ, 東西方向は平野が開けているという周辺 の地形から，風が東西方向に吹き抜けるためである.

風向·風速と流向·流速の関係に着目寸ると, 薄灰色の 縦帯で示す風向が北東〜東の時に, 中海では N-a で強い 北西流が発生し， N-b では西〜南西流となる. しかし, 同じ北東〜東風時に宾道湖内の観測地点 S-a, S-b にお ける流向の変化には中海のように決まった傾向はみられ ない. このように, 同じ気象外力下においても, 宍道湖 の流動は中海と異なっていることがわかる。これは湖の 平面形状が複雑に入り組んでいる中海では各観測地点に おいて主流軸方向が明確に定まるのに対して, 宍道湖の 平面形状は東西に長い単純な矩形状であるため, 流れの 自由度が大きく主流軸方向が明確でないことが原因の一 つとして考えられる. また, 中海と宾道湖の成層状態の 違いや河川水の流入が流れに影響していることも考えら れる. 河川水の流入が流向・流速に及ぼす影響を, 大津で 観測された斐伊川の流量を用いて検討する。斐伊川は中 海·宾道湖に流入する河川の全流域のうち約半分を占め る. その斐伊川河口部に近い観測地点 S-a と遠い地点 S-b の流向・流速を比較する.観測期間中は大きな出水はなく， 大津流量は期間を通じて $100 \mathrm{~m} 3 / \mathrm{s}$ 未満である。期間中 10/9，10/20，10/25にわずかな出水が生じているが，こ のときに S-a の流向・流速が他の時期, 他の地点と比べて 

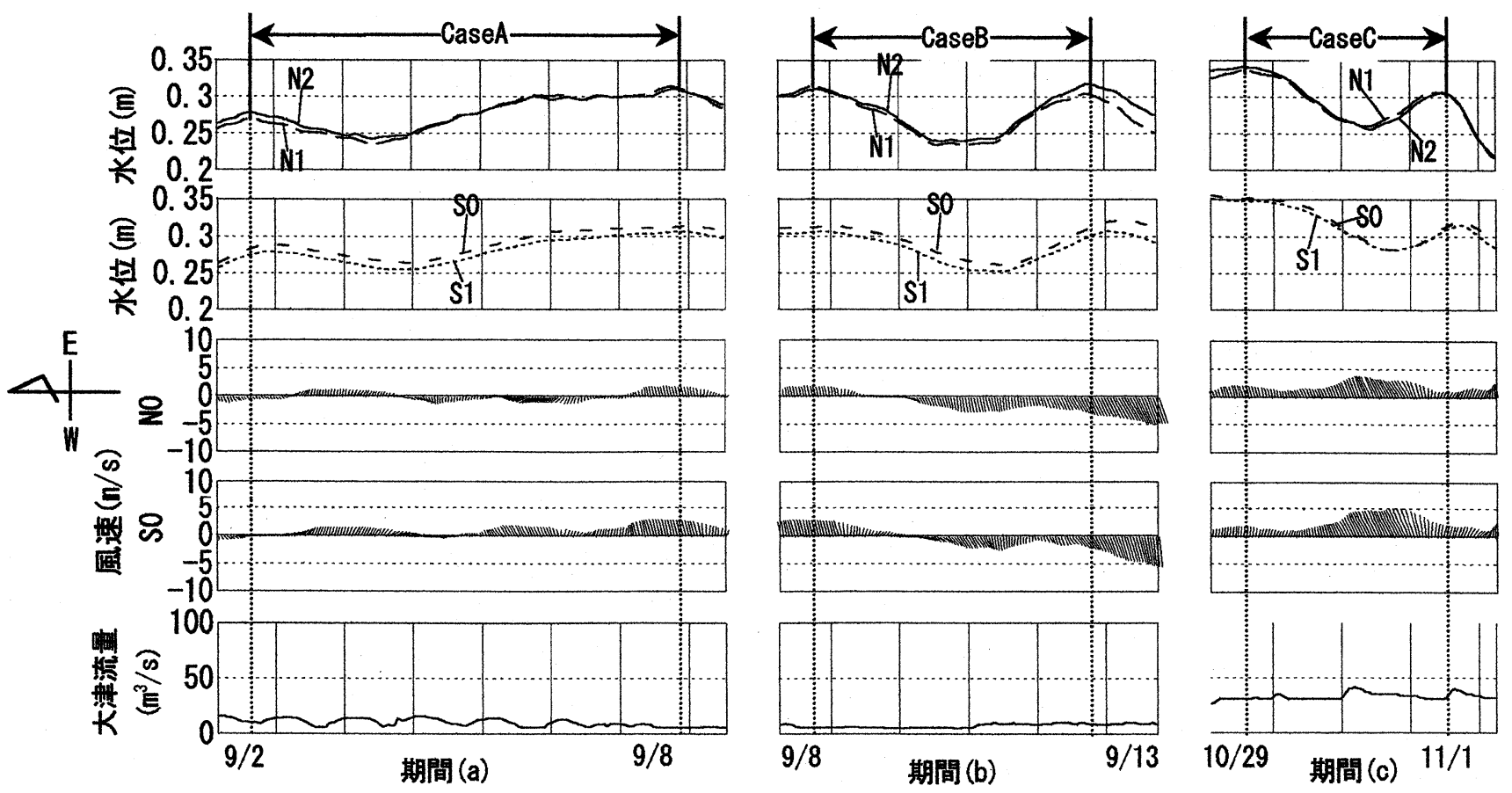

图-4 観測地点 N1，N2, S1, S0 における気圧変化に伴う水位変動 CaseA, B, $\mathrm{C}$ と 同期間中の $\mathrm{N} 0, \mathrm{~S} 0$ 風向・風速，大津流量（1998 年）

特に変化している様子はない，このことから，観測期間 中において，河川水流入が中海·宍道湖の流向·流速に及 ぼす影響は小さいといえる.

\section{4. 気圧変化に伴う水位変動の伝播}

\section{（1）気圧変化に伴う水位変動の抽出}

中海, 宾道湖の水位変動を引き起こす主要因には, (1) 天文潮および(2)気圧変化により生じる外海の水位変動, (3)湖上を吹く風の吹き寄せ効果，そして(4)河川水の流入 による水位上昇の 4 つが挙げられる，本研究では，実測 された水位データから(2)気圧変化に伴う水位変動を抽出 して検討を行うため, 以下に示す方法により(1)天文潮に よる水位変動成分, (3)風の吹き寄せ効果, (4)河川水の流 入の影響を取り除く.

图一3(a)に 1998 年 9/3 9/12 の 10 日間における観測 地点 No での気圧を示す．(b)に観測地点 N2, S1 で実測 された水位を示す.

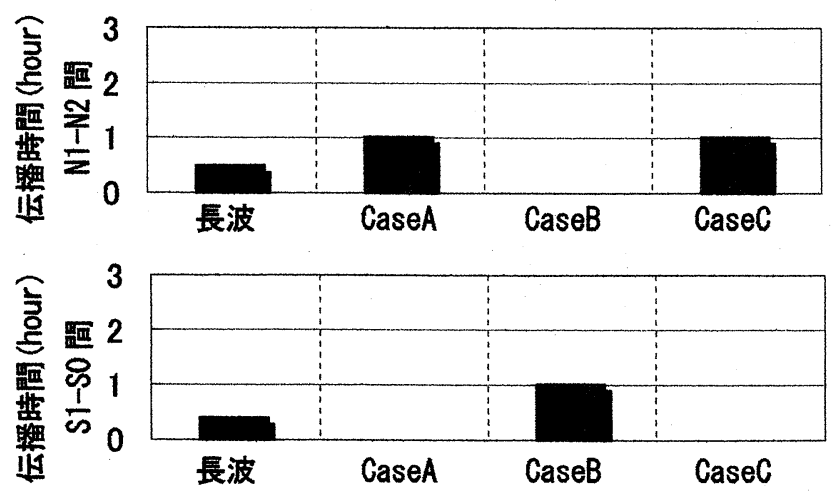

図-5 長波と水位変動 CaseA, B, C の伝播時間
まず，天文潮の卓越周期はおよそ 12.5 時間と 25 時間 の二つであるので，実測された水位変動の 25 時間移動 平均を取ることにより天文潮による水位変動を取り除く. (c)に示すように 25 時間移動平均をとった水位変動には 12.5 時間周期および 25 時間周期の変動はほとんど見ら れず,気圧の変化に数時間遅れて対応していることから， 概ね気圧変化による水位変動を示しているといえる. (d) は，(b)実測された水位変動から(c)25 時間移動平均水位 変動を差し引いたもので, 概ね天文潮による水位変動を 示す.

さらに，(3)風の吹き寄せ効果と(4)河川水の流入による 水位変動を取り除くため, 観測地点 No, S0 での風が弱 く, 大津流量が少ない期間を選ぶ.

図-4 は, 風が弱く大津流量の少ない三つの期間(a), (b), (c)における N1，N2，S0，S1 での気圧変化に伴う水位 変動を示す. 期間(a), (b), (c)に生じた水位変動の頂点汃 ら頂点まで一波長分をそれぞれ CaseA，B，C とする. 図-4の風向・風速は水位と同様に 25 時間移動平均をと ってある. 風向は上向きが東方向一吹く風を，下向きが 西方向一吹く風を示す。

\section{（2）気圧変化に伴う水位変動の中海内および穴道湖内に おける伝播時間}

图-5に，長波が N1-N2 間，および $\mathrm{S} 1-\mathrm{S} 0$ 間を伝播す る時間と, CaseA, B, C の水位変動が実際に N1-N2 間, およびS1-S0 間を伝播した時間を示す。

長波の伝播時間は, 次式で示される長波の波速 $C$ より 求めた.

$$
C=\sqrt{g h}
$$


(a)

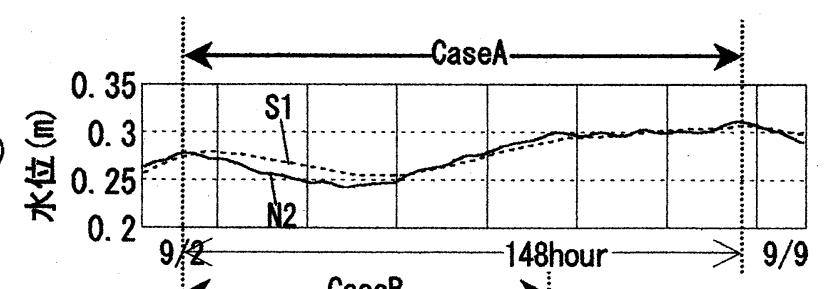

(b)

(c)

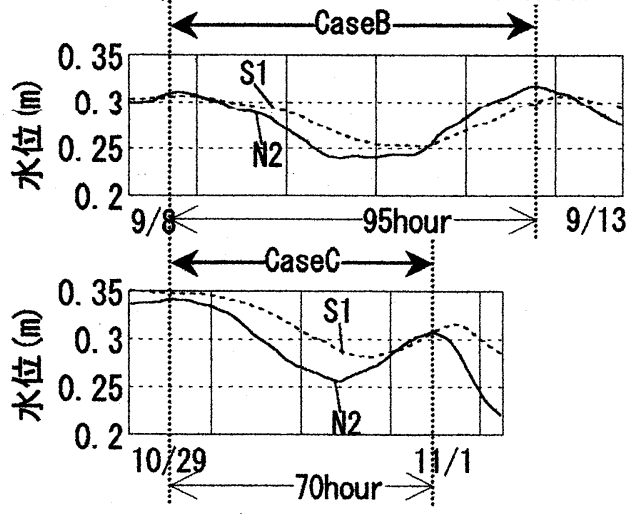

(d)

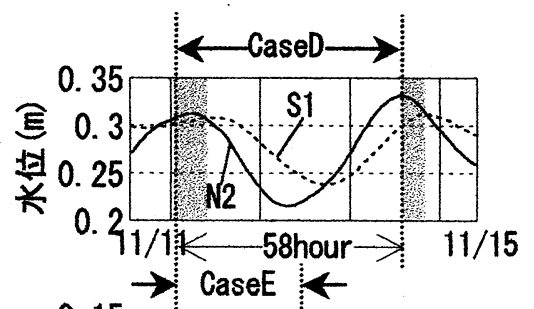

(e)

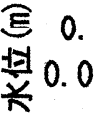

15

(f)

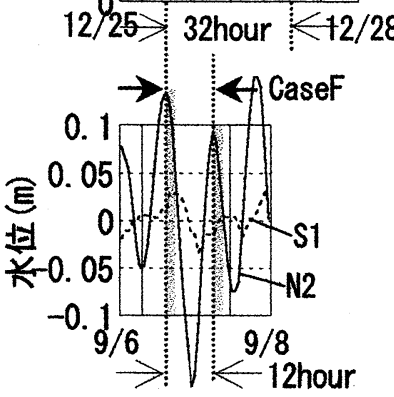

図-6 観測地点 N2，S1 における水位変動 CaseA, B, C, D, E, F とその周期（1998 年）

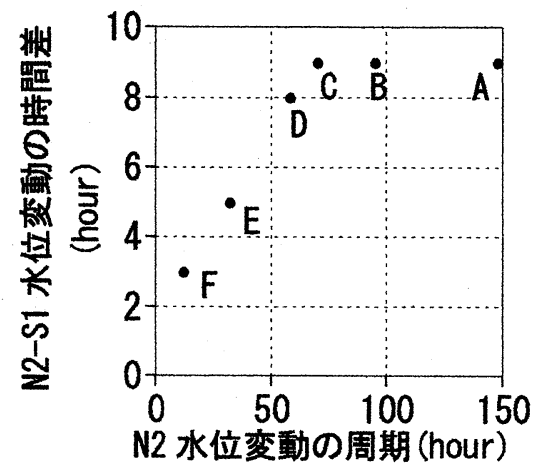

图-7 N2, S1 水位变動の時閒差と周期の関係

ここに, $g$ : 重力加速度, $h:$ 水深である. 長波の伝 播時間は N1-N2 間が 29 分 (0.48 時間) であり, S1-S0 間が 21 分（0.36 時間）である.

水位変動 CaseA，B，C の伝播時間は，2 地点の水位 変動の相互相関を 1 時間ずつ時間差をつけてとり, 最も 相関係数が大きくなる時間差を伝播時間とした.

図-5より,水位変動 CaseA, B, C の伝播時間はN1-N2 間，S1-S0 間の両区閒ともに長波と概ね一致している. このことより, 水位変動は中海内, 穴道湖内において長 波で伝播していることがわかる.

\section{（3）大橋川を挟む 2 地点の水位変動の間に生じる時間差}

大橋川を挟む 2 地点, $\mathrm{N} 2$ と $\mathrm{S} 1$ での水位変動の間に生 じる時間差について検討する. 図一6に観測地点 $\mathrm{N} 2, \mathrm{~S} 1$ での水位を示す，(a)，(b)，(c)は，図-4で示した気圧変 化に伴う水位変動CaseA, B, Cである. (d), (e)は, CaseA, $\mathrm{B}, \mathrm{C}$ と同様に風吢弱く, 大津流量が少ない期間の気圧 変化に伴う水位変動であり, CaseD, E とする.(f)は, 図-3(d)に示した天文潮による水位変動のうち特に風が
弱かった期間の水位変動の一波長分であり, CaseF とす る.また，それぞれの水位変動の周期を図中に示す.

中海内の 2 地点 $\mathrm{N} 1$ と $\mathrm{N} 2$, 穴道湖内の 2 地点 $\mathrm{S} 1$ と $\mathrm{S} 0$ における水位変動のあいだに生じる時間差は図-5で示 したように 0 時間または 1 時間であり，ほとんど時間差 がない，それに対し図-6より，大橋川を挟む N2 と S1 における水位変動の間には数時間の差が見られる.この 時間差は一般に 7 10 時間であり，水位変動が中海から 宍道湖へ伝播する際に，大橋川が中海，宾道湖間の水移 動を制限する抵抗体となっていることに起因する)，7).

図-7 に水位変動 CaseA，B，C，D，E，F の周期と， 相互相関法により求めた N2 での水位変動と S1 での水 位変動の時間差の関係を示す。この図より，水位変動の 周期が長いほど $\mathrm{N} 2$ と $\mathrm{S} 1$ の水位変動の時間差が長い傾 向がみられる. この理由を $\mathrm{N} 2$ の水位と $\mathrm{S} 1$ の水位との 関係がもっとも顕著に見られる水位変動 CaseD と CaseF を比較し考察する. 本研究で着目しているような 河川水の流入の影響がない場合は，宾道湖の水交換は大 橋川を介した中海との交換だけであるため, 宾道湖の水 位変動は中海との相対水位に支配される.すなおち, 図一 6(d)，(f)にみられるようにN2（中海）の水位が S1（宾 道湖）の水位より相対的に高い時に S1 水位は上昇し, $\mathrm{N} 2$ 水位と $\mathrm{S} 1$ 水位がおよそ等しくなる時に $\mathrm{S} 1$ 水位は頂 点を取り, 逆に $\mathrm{N} 2$ 水位が $\mathrm{S} 1$ 水位より相対的に低くな ると $\mathrm{S} 1$ 水位注下降する. このときに生じる $\mathrm{N} 2$ 水位の 頂点と S1 水位の頂点との時間差（図中に灰色の帯で示 す）が $\mathrm{N} 2$ 水位変動と $\mathrm{S} 1$ 水位変動の時間差である.

CaseD と CaseF からもわかるように, N2 水位変動の周 期が長いほど, $\mathrm{N} 2$ 水位の頂点と $\mathrm{S} 1$ 水位の頂点との時間 差は長くなる. 
(a)

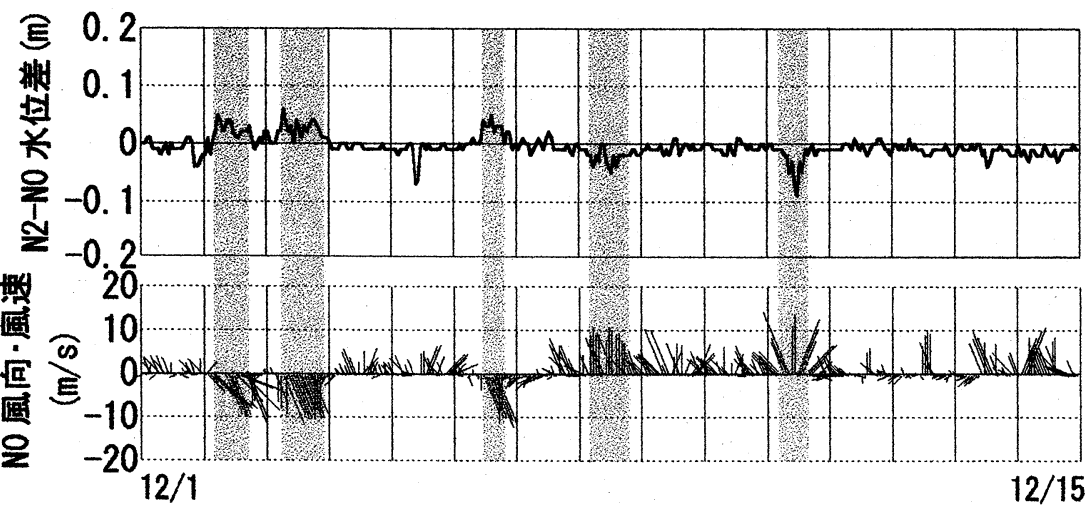

(b)

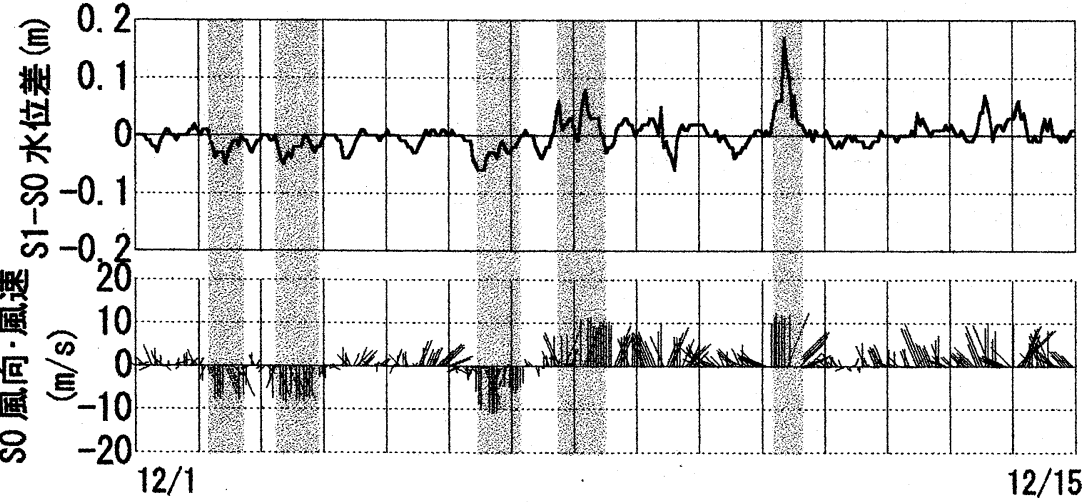

図-8 $\mathrm{N} 2-\mathrm{N} 0$ 水位差と $\mathrm{N} 0$ 風向·風速，及び $\mathrm{S} 1-\mathrm{S} 0$ 水位差と $\mathrm{S} 0$ 風向·風速の 関係（1998/12/1 12/15)
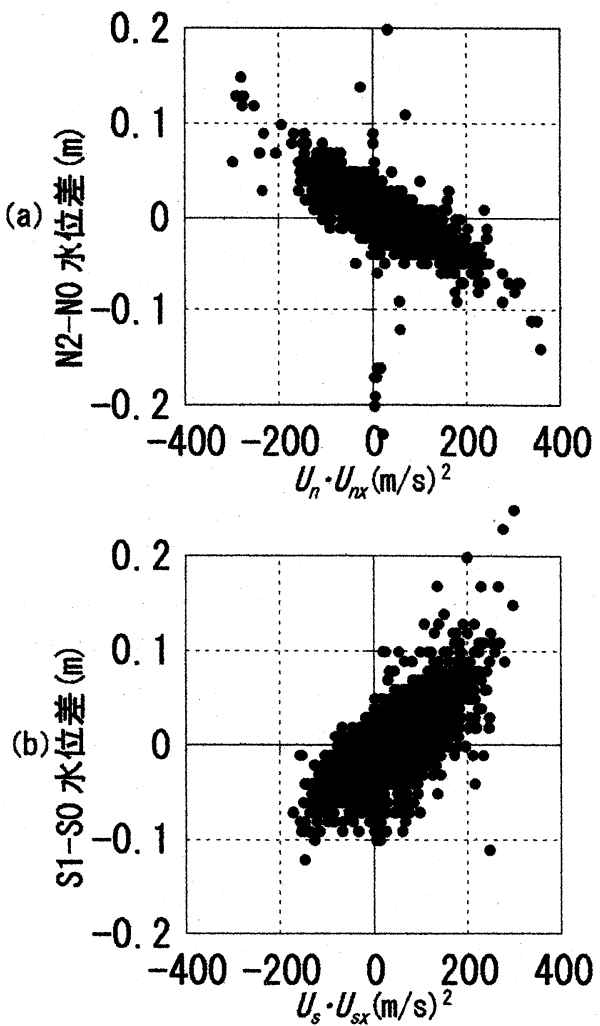

図-9 水位差と風速の関係（1998 年）

\section{5. 風の吹き寄せによる水位変動}

图-8(a)に観測地点N0における水位とN2における水 位の差と観測地点 N0で測定された風向·風速を示し, (b) に観測地点 S0 における水位と $\mathrm{S} 1$ における水位の差と観 測地点 S0 で測定された風向・風速を示す，期間は 1998 年 12/1 12/15 である.（a)の No と.N2 の水位差は，值 が正のときに N2 水位が No 水位より相対的に高い状態 を表し，值が負のときに N2 水位が N0 水位より相対的 に低い状態を表す.風向は, 上向きが東方向へ吹く風を, 下向きが西方向へ吹く風を表す. 図中の縦帯で示す部分 より，風向が西方向のとき $\mathrm{N} 2$ 水位が上昇し，逆に風向 が東方向のとき N2 水位が下降することがわかる.

(b)の S0 と S1 の水位差は, 值が正のときに $\mathrm{S} 1$ 水位が $\mathrm{S} 0$ 水位より相対的に高く, 值が負のときに $\mathrm{S} 1$ 水位が低 い状態を表す. 風向が西方向のとき $\mathrm{S} 1$ の水位が上昇し, 風向が東方向のとき $\mathrm{S} 1$ の水位が下降する.このように, 中海と宾道湖では吹き寄せにより数 $\mathrm{cm}$ 程度の水位変動 が生じている．また，(a)と(b)を比較すると No， So で 観測される風が同程度の風速であれば(b)の $\mathrm{S} 0$ と $\mathrm{S} 1$ の 水位差のほうが大きく変動する傾向がみられる.

吹き寄せにより生じる水面勾配の釣合い式は次式で 示される 8), 9),

$$
\frac{d \eta}{d x}=\frac{\tau}{\rho g h}
$$

ここに， $\tau$ : 湖面に作用するせん断力, $\rho$ : 水の密 度, $g$ : 重力加速度, $h$ : 局所水深, $x$ 距離, $\eta$. 水 位の変動量である．また，風により湖面に作用するせん 断力 $\tau$ は次式で示される.

$$
\tau=\frac{1}{2} \rho_{a} C_{f} U_{a} U_{a x}
$$

ここに, $C_{f}$ : 水面の抵抗俰数, $U_{a}$ : 湖面上の風速, $U_{a x}$ : 風速の長軸方向成分, $\rho_{a}$ : 空気の密度である. したがっ て, 吹送距離 $L$ の区間上で風速, 水深 $h$ が一定であると 仮定すると, 式 (2), 式（3）より水位変動量 $\eta$ は次式 で示される.

$$
\eta=C_{f} L \frac{\rho_{a}}{\rho} \frac{U_{a} U_{a x}}{2 g h}
$$

いま, 水位変動量 $\eta$ を $\mathrm{N} 0$ と $\mathrm{N} 2$ の水位差 (これを $\eta_{n}$ と する）および $\mathrm{S} 0$ と $\mathrm{S} 1$ の水位差（これを到とする）と考 え，風速の長軸方向成分 $U_{a x}$ を $\mathrm{N} 0$ および $\mathrm{S} 0$ で測定され た風向・風速（それぞれ $U_{n}, U_{s}$ とする）の東西方向成分 （それぞれ $U_{n x}, U_{s x}$ とする）と考える.

図-9(a)に $\eta_{n} 亡 U_{n} \cdot U_{n x}$ の関係を，(b)に $\eta_{s}\left\llcorner U_{s} \cdot U_{s} D\right.$ 関係を示す（a)，(b)ともに相関のあることがわかる. 相 
関係数は(a)が-0.68，(b)が 0.64 である.

式（4）と図-9より，中海と实道湖それぞれの湖にお ける水面の抵抗係数 $C_{f}$ の值を求めると, 中海では $C_{f}=$ $4.3 \times 10^{-3}$, 穴道湖では $C_{f}=3.0 \times 10^{3}$ となった.ここに， 観測地点 N0 と N2 の距離を $6200 \mathrm{~m}$, 観測地点 $\mathrm{S} 1$ と $\mathrm{S} 0$ の距離を $7400 \mathrm{~m}, \mathrm{~N} 0-\mathrm{N} 2$ 間の水深を中海の平均水深 5.4 $\mathrm{m}, \mathrm{S} 1-\mathrm{S} 0$ 間の水深を宾道湖の平均水深 $4.5 \mathrm{~m}$ と与えて 求めた。 ただし，観測地点 No，S0 における風速の測定 高さはそれぞれ T.P.14.1mと T.P.6.1mであり異なるため, 両者の比較はできない。

風の吹き寄せにより生じる数 $\mathrm{cm}$ の水位差によって, 密度成層を形成している中海では大きな密度界面勾配が 生じ，条件によっては中海の下層に存在する高濃度の塩 水が大橋川に流入することがある ${ }^{10}$. また，宍道湖にお いても風による水面勾配によって中海と同様に大きな密 度界面勾配が発生することや，風による水面勾配が下層 水の移動を引き起こすことが予想される.

このように，風の吹き寄せにより中海・宍道湖におい て生じる水位差は数 $\mathrm{cm}$ と小さいが，中海 - 大橋川 - 宍 道湖の流動・水質に大きな影響を与えている.

\section{6. 結論}

気象外力, 湖内流動, 水位変動について, 連結系汽水 湖である中海 - 大橋川 - 实道湖を一体的に検討した結果 得られた結論を以下に示す。

（1）中海と宍道湖に作用する気象外力（気圧と風）を 比較し, その気象外力（風）により生じる湖内流動の違 いを検討した。 中海（N0）と宾道湖（S0）の気圧変動 には時間のずれがなく值も一致しており，二つの湖上で の気圧差はない，中海と宾道湖ともに北東〜東，および 南西〜西方向の風が卓越しており，このときに強風とな りやすい.二つの湖上の風向・風速の変動には時間のずれ がほとんどなく，概ね一致している．すなわち，中海と 实道湖には同じ様な気象外力が作用していることを確認 した.

しかし，中海と宍道湖上の風向・風速が概ね一致して いるにもかかわらず，二つの湖の水面下 $1 \mathrm{~m}$ 地点に生じ る流れは異なっている．中海では流軸方向が定まってお り, 強風時には明確な流れの方向を有する吹送流が確認 できるが，宍道湖では強風時においても流速が小さく， 風向と流向の関係も明確でない.この理由として, 中海

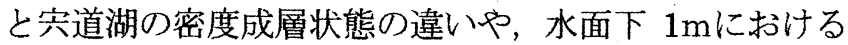
流れは風向と同一方向に流れる吹送流ではなく, 湖の平 面形状の影響を受けて流れ方向を制限された流れとなっ ていることが挙げられる. 中海の平面形状は入り組んで いるため各観測地点において主流軸方向が明確に定まる のに対して, 宍道湖の平面形状は東西に長い単純な矩形 状であるため流れの自由度が大きく主流軸方向が明確で ない。
（2）気圧変化により日本海で生じた水位変動が中海 大橋川 - 宾道湖の水域全体一伝わる機構を, 中海内, 穴 道湖内, 大橋川上下流端の三つの区間に分けて検討した. 中海内, 宍道湖内において水位変動は長波の形式で伝播 する. それに対し，大橋川上下流端での水位変動の時間 差は, 中海内, 穴道湖内とは異なり大橋川による通水の 抑制に起因するもので, 中海における水位変動の周期に 依存する. 既往の研究で大橋川上下流端での水位変動の 時間差は天文潮成分より気象潮成分のほうが長いことが 確認されているが，これは水位変動の周期が異なること が大きな要因である.

（3）風の吹き寄せにより，中海内，宍道湖内において 数 $\mathrm{cm}$ 程度の水位変化が生じていることを確認し，水面 の抵抗係数を求めた. 水位変化は数 $\mathrm{cm}$ 程度と小さいが, 密度成層を形成している中海, 宾道湖においては大きな 密度界面勾配をもたらし，これが大橋川を介して水域の 流動，水質に大きな影響を与えていると考えられる.

\section{参考文献}

1）橋谷博, 奥村稔, 藤永薫, 近藤邦男, 清家泰 : 穴道湖・中 海の水質変動に与える気象・海象の影響一(その 2)1982〜 1991 年の水質変動と気象 5 因子, 山陰地域研究（自然環 境) 第 8 号, 1992.

2）橋谷博: 各種の気象条件が中海・宾道湖の水環境に及ぼす 影響, 陸水学雑誌, 第 55 巻/No.1, pp.75-76, 1994.

3）福岡捷二, 黒川岳司, 日比野忠史, 鈴木篤, 中村剛, 上原 浩: 中海における気象変化に伴う流れと貧酸素水塊の挙動, 土木学会論文集 No.636/VII-13, pp.61·79, 1999.

4）黒川岳司, 福岡捷二, 五道仁美, 松下智美, 三浦心 : 宾道 湖における湖内流動と水質変化の特徴, 第 56 回年次学術 講演会講演概要集 II·196, pp.392-393， 2001.

5）福岡捷二, 松下智美, 三浦心, 黒川岳司, 船橋昇治, 中村 幹雄: 連結系汽水湖における塩分変化特性, 水工学論文集, 第 46 巻, pp.899-904, 2002.

6）日比野忠史：連結系汽水域での流動一気候·気象の変化が 流れに及ぼす影響一, 1996 年度（第 32 回）水工学に関す る夏季研修会講義集, A コース, pp.A·7·1·20， 1996.

7) Ishitobi, Y., Kamiyama, H. and Itogawa, H. : Tidal, Meteorological and Hydrological Effects on the Water Level Variation in a Lagoon, Lake Shinji, Jpn. J. Limnol, Vol.54, No.1, pp.69-79, 1993.

8）石田享平, 鈴木洋之, 長谷川和義 : 多点同時計測法による 定山渓ダム貯水池での水面変動の計測と解析, 土木学会論 文集, No.628/II·48, pp.163·176, 1999.

9）服部昌太郎: 土木系大学講義シリーズ, 海岸工学, コロナ 社, 1987.

10）松下智美, 三浦心，福岡捷二: 連結系汽水湖における流れ と水質分布に及ぼす密度界面の役割, 第 57 回年次学術講 演会講演概要集 II·136, pp.271·272， 2002.

(2002. 9. 30受付) 